Марија М. Гордић

Прегледни рад

mgordic@kg.ac.rs

UDK 001.89:347.78

Весна 3. Абадић

vesnaa@kg.ac.rs

Универзитетска библиотека у Крагујевцу

\title{
DORA: ДЕКЛАРАЦИЈА О ПРОЦЕНИ ИСТРАЖИВАЧКОГ РАДА У СВЕТЛУ ОТВОРЕНЕ НАУКЕ
}

Сажетак: Парадигма отворене науке савременог академског друштва обухвата промене у целокупном научноистраживачком процесу, почев од отвореног приступа подацима, отвореног рецензирања, до приступа научним радовима. Свесни чињенице да је неопходна и промена у евалуацији научноистраживачког рада, да се злоупотребљавају и често погрешно тумаче наукометријски параметри, поготово фактор утицаја часописа, покренуте су декларације на глобалном нивоу како би се заузео заједнички став свих учесника у евалуацији научних резултата. Једна од првих иницираних декларација, DORA (Declaration on Research Assessment), конституисана је пре више од пет година. Сваке године, број институција и појединаца који приступају/потписују Декларацију расте, а тежња да се наука ослободи бремена комерцијалних издавача и постане заиста отворена, чини је све актуелнијом.

Кључне речи: фактор утицаја часописа, цитатне базе, DORA, План C.

\section{DORA и Фактор утицаја часописа}

Декларација о процени истраживачког рада DORA (Declaration on research Assessment) ${ }^{1}$ настала је крајем 2012. године у Сан Франциску. Иницирала ју је група уредника и издавача на годишњем састанку Америчког

1 https://sfdora.org/ (преузето 2. 4. 2019). 
друштва за биологију ћелија (ASCB - American Society for Cell Biology). Декларација идеалистички изражава неопходну потребу за променама у начину на који се врши евалуација у науци, те позива истраживаче, институције, финансијере и издаваче научне литературе да буду уздржани у коришћењу постојећих Фактора утицаја часописа (JIF - Journal Impact Factor). ${ }^{2}$

Декларација претендује да уведе такав систем оцењивања где ће садржај сваког истраживачког рада појединца бити важнији од наслова часописа или платформе на којој је објављен. У пракси, тенденције су такве да када се процењује вредност научног доприноса истраживача, фокус је усмерен на Фактор утицаја самог часописа, а не на сам квалитет рада о коме је реч, чему сведоче бројни примери погрешно протумачен, јер је иницијално настао као помоћ библиотекарима при одлучивању око избора и набавке одређеног часописа. ${ }^{4}$ Он не одражава вредност појединачног истраживачког рада, већ само просек цитата везаних за наслов изабраног научног часописа у последњој години. Сам број цитата неког рада представља несавршену меру квалитета и његове утицајности (Curry, 2018). Фактори утицаја као просечне вредности различитих параметара прикривају квалитете радова у истом часопису. Тако, неретко, могу се уочити наслови са веома високим бројем цитата, за разлику од наслова из истог часописа без нотификација цитираности који су присутни само захваљујући примамљивим метрикама часописа. ${ }^{5}$ Тренутно, на веб-страници DORA ${ }^{6}$ евидентиране су 1.282 институције и 14.004 појединца потписника Декларације.

\section{Промене у евалуацији}

Научна заједница је свесна чињенице да постојећи несавршени вид евалуације истраживачког рада обликује науку. Досадашња пракса је по-

https://sfdora.org/ (преузето 2. 4. 2019).

3 Philip Campbell, „Escape from the impact factor”, Ethics in science and environmental politics ESEP vol. 8, (2008), https://www.int-res.com/articles/esep2008/8/e008pp1.pdf_(преузето 4. 4. 2019).

4 San Francisco Declaration on Research Assessment, https://sfdora.org/read/ (преузето 5. 4. 2019).

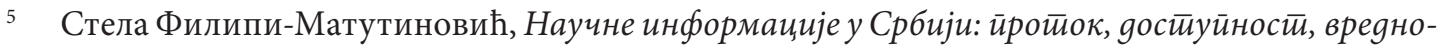
ване (Београд: Српско биолошко друштво, 2014), 43, http://arhiva.unilib.rs/unilib/edukacija/ Naucne\%20informacije\%20u\%20Srbiji.pdf (преузето 5. 4. 2019).

6 Потписници DORA-e https://sfdora.org/signers/ (приступљено 5. 4. 2019). 
казала да најчешће и лоше донесени институционални правилници дефинисањем неопходних услова за избор у звања, захтевају од истраживача да прате праксу публиковања у часописима са високим Фактором утицаја, у нади да ће им то обезбедити бољу претраживост и видљивост рада, а самим тим и већу цитираност. Због тога се може рећи да су квантитативни показатељи постали сами себи циљ, нарушавајући саму науку. Да ова тврдња буде драстичнија, показују и плаћени бонуси везани за Факторе утицаја на појединим универзитетима у свету (нарочито у Кини). 7 У Републици Србији на снази је Правилник о поступку, начину вредновања и квантитативном исказивању научноистраживачких резултата истраживача („Сл. гласник PC” бр. 24/2016 и 21/2017). ${ }^{8}$ Задатак DORA декларације је да убрза промене у овој сфери. Примарни циљ је успостављање ефикасне и непристрасне методе евалуације научноистраживачког рада.

Декларација DORA је установљена са прецизно исказаним обавезама свих учесника у процесима везаним за резултате истраживања, и представља одличан алат за правичну евалуацију (Curry, 2018). Стивен Кари (Stephen Curry) описује неке од активности на конкретној примени Декларације, као што су идентификација и ширење примера добре праксе и јачање реформи система евалуације, приказане на конференцијама и онлајн дискусијама. Једна од иницијатива које се разматрају је решење концентирисаних иситраживачких биоірафија, што би требало да омогући истраживачима да сумирају најважније истраживачке доприносе, менторство, друштвени ангажман и друге важне активности. Такав приступ може имати и недостатке, јер се отварају и могућности за манипулацију. С друге стране, сви покушаји и „експерименти” вредни су напора да се трасира прави пут ка свеобухватнијој евалуацији. Неопходна је перманентна комуникација у читавом ланцу научноистраживачког процеса, отворено рецензирање и приступ истраживачким подацима, што је и предуслов пуних принципа отворене науке. ${ }^{9}$

Stephen Curry, „Let's move beyond the rhetoric: it's time to change how we judge research”, Nature vol. 554, no. 147 (2018), https://www.nature.com/articles/d41586-018-01642-w (преузето 13. 5. 2019).

8 http://www.mpn.gov.rs/wp-content/uploads/2017/03/Pravilnik-2017-preciscen-tekst.pdf (преузето 3. 4. 2019).

9 Абадић Весна и Марија Гордић, „Платформа за отворену науку - обавезност публиковања у отвореном приступу у Републици Србији”, Инботекека год. 18, бр. 2 (2018), https://infoteka. bg.ac.rs/ojs/index.php/Infoteka/article/view/2018.18.2.4_sr (преузето 4. 4. 2019). 


\section{План C}

Потребно је поменути и друге иницијативе које позивају на промене у овој области да се евалуација истраживачког рада пренесе са нивоа научног часописа на ниво научног рада, што значи минимизацију утицаја Фактора утицаја. Најзначајнији је Лајgенски манифести о вреgновағу истираживача ${ }^{10}$, усвојен у Лајдену, јуна 2014. године, у коме се позива на десет принципа приликом вредновања научних истраживања, у циљу отклањања злоупотребе метрике и њеног погрешног тумачења. Превод на српски језик дали су проф. др Снежана Смедеревац и проф. др Дејан Пајић са Универзитета у Новом Саду, у оквиру BE-OPEN пројекта, 2017. године. ${ }^{11}$

Последња иницијатива европског конзорцијума који окупља највеће националне истраживачке агенције и финансијере из 27 европских земаља Science Europe ${ }^{12}$, јесте доношење „Плана C”13, усвојеног септембра 2018. године, а којим се од научника и истраживача чији је рад финансиран од стране државних институција захтева обавезност публиковања научних и стручних радова искључиво у отвореном приступу и под лиценцама отвореног садржаја (Creative Commons ${ }^{14}$ ). Овај програм ступа на снагу од 1. јануара 2020. године. Истовремено се придаје значај отвореним архивама и институционалним репозиторијумима, при чему хибридни часописи у отвореном приступу нису опција. Ови предлози су резултирали потписивањем петиција у академским круговима, са захтевом да се комерцијални издавачи елиминишу из тока научних информација. До сада је 11 националних агенција за финансирање у Европи потписало План С. ${ }^{15}$ Такође, све чешће се на интернету појављују текстови који детаљно описују начине за превазилажење ових проблема, наводећи начине и алате којим истраживачи могу да дођу до пуног текста оних радова који не кореспондирају са

10 Лајденски манифести о вредновағу исирраживача http://www.leidenmanifesto.org/uploads/ 4/1/6/0/41603901/lajdenski_manifest_serbian.pdf_(преузето 2. 4. 2019).

11 http://open.ac.rs/docs/Lajdenski-manifest.pdf_(преузето 2. 4. 2019).

12 https://www.scienceeurope.org/about-us/member-organisations/ (преузето 2. 4. 2019).

13 https://www.coalition-s.org/about/ (преузето 13. 5. 2019).

14 https://creativecommons.org/licenses/ (преузето 13. 5. 2019).

15 Else Holly, „Radical plan to end paywalls”, Nature vol. 561 (2018): 17, https://www.nature.com/ articles/d41586-018-06178-7 (преузето 5. 4. 2019). 
комерцијалним издавачима и подацима о њиховим цитатима. ${ }^{16}$ Овај потез је посебно интересантан истраживачима који објављују у глобално цењеним часописима који се не реферишу у WoS или Scopus цитатним базама искључиво због тога што им то није императив или жеља. Иако постоји велика бојазан и резервисаност аутора око пријема овако публикованих радова и њихових резултата, неретко је случај да се, у врло кратком временском периоду, детектује велики број цитата публикованог рада. ${ }^{17}$ Ово је посебно важно ако се зна да се већина научних чланака објављених у комерцијалним часописима, уопште не цитира. ${ }^{18}$

Може се закључити да је разлика у Фактору утицаја између комерцијалних наслова и осталих наслова научних часописа у режиму златног отвореног приступа најчешће претерана. Реакције комерцијалних издавача су оштре и забрињавајуће, што указује да ће транзиција ка потпуно Отвореној науци бити тешка. ${ }^{19}$

Да је помак могућ, говори податак из регистра ДОАЈ (Directory of Open Access Journals) у коме је евидентирано 12.954 часописа $^{20}$, од којих је 73,7\% у режиму златног отвореног приступа, а свега 26,3\% захтева плаћање надокнаде за публиковање - Article Processing Charges (APC).

16 Jeltsch Michael, „The battle between the big publishers and the sciencific community”, Michael's Domain (2019), https://michael.jeltsch.org/price_of_knowledge?fbclid=IwAR0XODCfiNoldauq 1ZpDpRwHYipZoYHaZ5pdsEHSGsmu-HHFs3KD3OYTfR8 (преузето 5. 4. 2019).

17 Jeltsch Michael, „Poor correlation on the Journal Impact Factor with scientific impact”, Michael's Domain (2019), https://michael.jeltsch.org/impact_factor (преузето 5. 4. 2019).

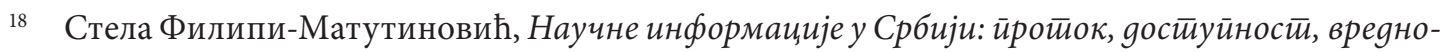
вате (Београд: Српско биолошко друштво, 2014), 43, http://arhiva.unilib.rs/unilib/edukacija/ Naucne\%20informacije\%20u\%20Srbiji.pdf (преузето 5. 4. 2019).

19 Else Holly, „Radical plan to end paywalls”, Nature vol. 561 (2018): 17, https://www.nature.com/ articles/d41586-018-06178-7 (преузето 5. 4. 2019).

20 DOAJ https://doaj.org/ (преузето 2. 4. 2019). 


\section{Закључак}

Генерално посматрајући, имплементација принципа Декларације о процени истраживачког рада из Сан Франциска може потпуно да промени начин евалуације науке. Последице по политику рада и опстанак комерцијалних издавача и тржишта научних часописа у тренутку када резултати научноистраживачких радова буду бесплатно онлајн доступни не могу се са сигурношћу предвидети. Међутим, извесно је да ће се пружити иста доступност научних резултата свим истраживачима. Финансијска способност неће бити један од кључних фактора приликом објављивања публикација у отвореном приступу. Објављени научноистраживачки радови ће се једино ценити по научном доприносу, уз нагласак на неопходност одржавања квалитета рецензија. Метрике чланка и часописа ће се разликовати показујући право стање њихових вредности. Да би све горе наведене изјаве прешле из домена хипотезе у праксу, потребно је да декларације и манифести не постоје као добри предлози, већ да се претворе у стратегије са конкретним корацима у имплементацији. Једино достизање свих циљева DORA декларације биће показатељ стварног преласка ка Отвореној науци уз уважавање свих њених принципа. 


\section{Literatura:}

1. Abadić, Vesna i Marija Gordić. „Platforma za otvorenu nauku - obaveznost publikovanja u otvorenom pristupu u Republici Srbiji”. Infoteka god. 18, br. 2 (2018) (na ćirilici), https://infoteka.bg.ac.rs/ojs/index.php/Infoteka/article/view/2018.18.2.4_sr (preuzeto 4. 4. 2019).

2. Campbell, Philip. „Escape from the impact factor”. Ethics in science and environmental politics ESEP vol. 8, (2008), https://www.int-res.com/articles/esep2008/8/ e008pp1.pdf (preuzeto 4. 4. 2019).

3. Curry, Stephen. „Let's move beyond the rhetoric: it's time to change how we judge research". Nature vol. 554, no. 7691, (2018), https:/www.nature.com/articles/ d41586-018-01642-w doi: 10.1038/d41586-018-01642-w (preuzeto 3. 4. 2019).

4. Directory of Open Access Journals, https://doaj.org/ (preuzeto 2. 4. 2019).

5. Filipi-Matutinović Stela. Naučne informacije u Srbiji: protok, dostupnost, vrednovanje. Beograd: Srpsko biološko društvo, 2014, http://arhiva.unilib.rs/unilib/edukacija/Naucne\%20informacije\%20u\%20Srbiji.pdf (преузето 5. 4. 2019).

6. Hicks, Diana, Paul Wouters, Ludo Waltman,Sarah de Rijcke, Ismael Rafols. „Bibliometrics: The Leiden Manifesto for research metrics”. Nature vol. 520, issue 7548, pp. 429-431, (2015).

7. Holly, Else. „Radical plan to end paywalls Top European research funders announce 'Plan S' to make all scientific works free to read". Nature vol. 561, pp. 17-18 https://www.nature.com/articles/d41586-018-06178-7_(preuzeto 5. 4. 2019).

8. Jeltsch, Michael, „The battle between the big publishers and the sciencific community", Michael's Domain (2019) https://michael.jeltsch.org/price_of_knowledge?fbclid=IwAR0XODCfiNoldauqlZpDpRwHYipZoYHaZ5pdsEHSGsmu-HHFs3KD3OYTfR8 (preuzeto 5. 4. 2019).

9. Jeltsch, Michael. „Poor correlation on the Journal Impact Factor with scientific impact", Michael's Domain (2019), https://michael.jeltsch.org/impact_factor (preuzeto 5. 4. 2019).

10. Leiden manifesto www.leidenmanifesto.org/uploads/4/1/6/0/41603901/lajdenski_ manifest_serbian.pdf (preuzeto 5. 4. 2019).

11. Nacionalni savet za visoko obrazovanje Republike Srbijae. „Tumačenje o vrednovanju rezultata istraživanja, Akt o uređivanju naučnih časopisa”, KoBSON, https:// kobson.nb.rs/upload/documents/MNTR/Dokumenti/SCI_lista_tumacenje.pdf (preuzeto 4. 4. 2019).

12. San Francisco Declaration on Research Assessment https://sfdora.org/read/ (preuzeto 5. 4. 2019). 


\section{Додатак: превод Декларације о процени истраживачког рада на српски језик ${ }^{21}$}

\section{Сан Франциско Декларација о йроцени исӣраживачкої раgа}

Све је израженији йрийисак неойхоgан gа се ӣобољиају начини ӣроие-

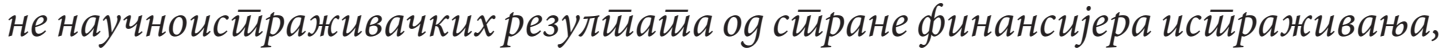

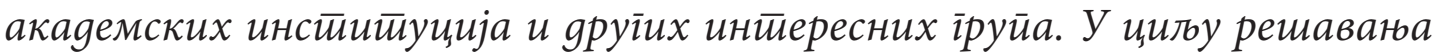

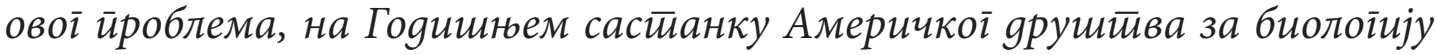
ћелија (АSCB), 16. 12. 2012. іолине у Сан Франциску (Калифорнија) састиала се ірруйа уреgника и издавача научних часойиса. Груйа је развита низ йрейорука, названих Сан Франциско Декларација о ирроцени истираживачкої раgа. Позивамо заиниеересоване симране из свих научних gисиийлина gа gају своју йодрику дояаваюем својих имена овој Декларацији.

Резулйайи научноі истираживаюа су бројни и разнолики и укључују: истираживачке чланке о новим сазнанима, йоgайке, реаіенсе и собйвер; ин-

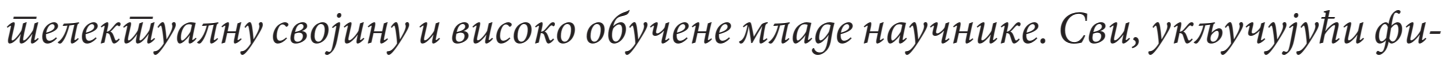

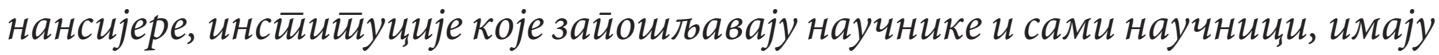

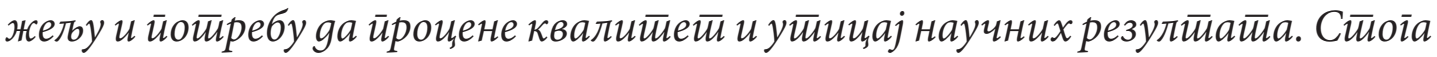

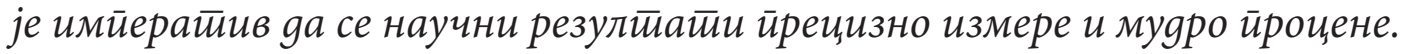

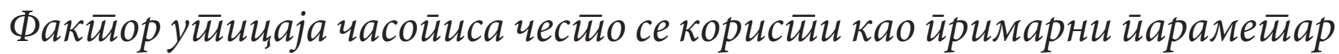

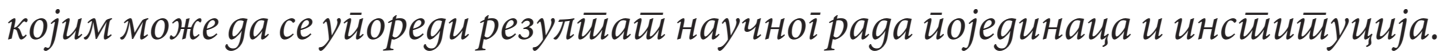

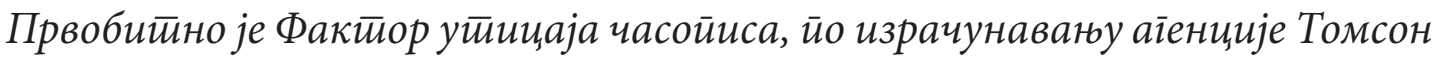

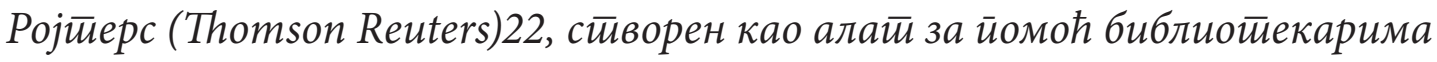
ириликом ояабира часойиса за набавку серијских йубликаиија, а не као ме-

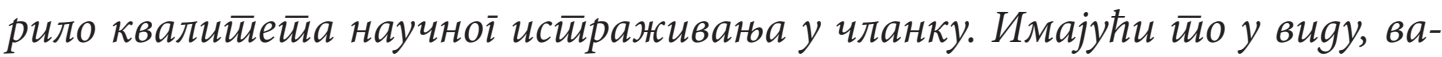

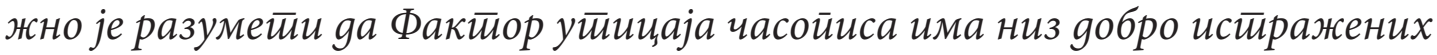

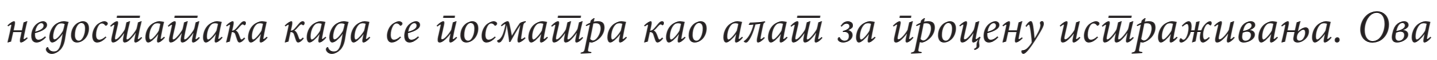
оіраничень укључују:

21 https://creativecommons.org/licenses/ (преузето 13. 5. 2019).

22 Else Holly, „Radical plan to end paywalls”, Nature vol. 561 (2018): 17, https://www.nature.com/ articles/d41586-018-06178-7_(преузето 5. 4. 2019). 
a) gистирибуиије ииитайа унуйар часойиса су веома неравномерне [1-3],

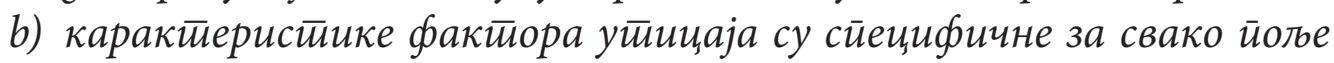
(истираживата): оне су састивљене ов више, веома различитих, иийова чланака, укључујући иримарне исираживачке раgове и ирреілеgне раgове [1, 4],

c) Фактиор уйицаја часойиса може битии изманийулисан („изиіран”) уређивачком йолитииком [5], и

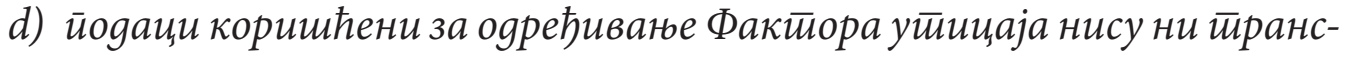

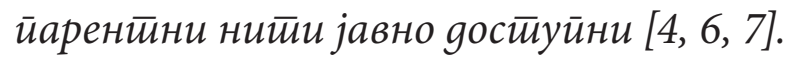

У насииавку доносимо низ ирреиорука за унаиређиване начина оцени-

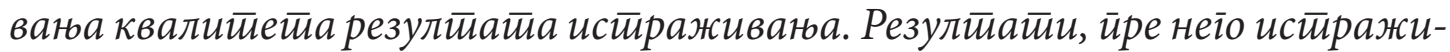
вачки члании, имаће све већи значај у ирочени ефикасностии исирраживана

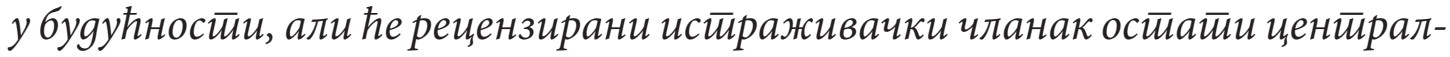
ни резултиати истираживаюа који йоказује ирроцену истираживања. Сйоїа, наше йрейоруке се иррвенстивено фокусирају на случајеве који се оgносе на исирраживачке чланке објавлене у рецензираним часойисима, али се моїу

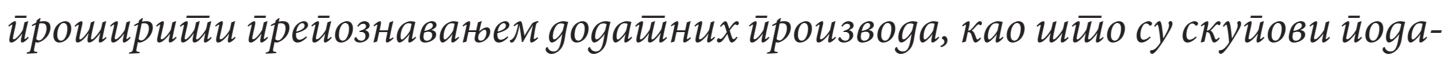

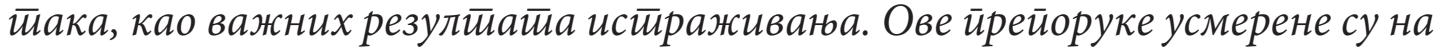
аіенције за финансираюе, акаяемске инстиитиције, часойисе, оріанизације које се баве метириком и индивияуалне истраживаче.

Велики број йема йокреће ове йрейоруке:

- йойреба gа се елиминише уйотиреба меитрике засноване на часойису,

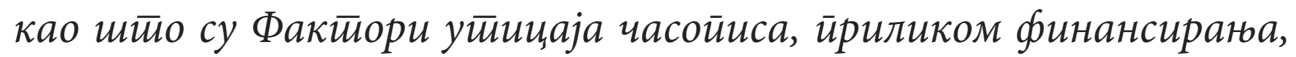
именовань и унаиређена;

- йотиреба gа се ирроцени истираживағе на основу сойсиивених заслуїа, а не на основу часойиса у коме је исирраживане објављено; и

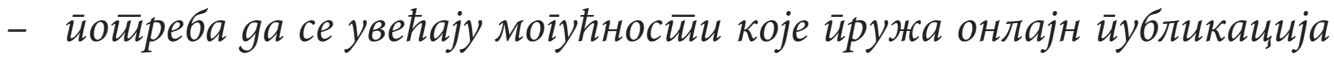
(као шито је изосиияльате нейоирребних оіраничена на број речи, илустирација и референии у чланиима, као и ироналажене нових индикатиора значаја и уйицаја).

Прейознајемо gа мноіе аіенције за финансиране, инсииитичиије, изgавачи и истираживачи већ йодстиччу йобољтане ираксе у ироцени истираживана. Овакви корации иочиюу gа добијају на замаху ка софисиичциранијим и смисленијим йристиуйима евалуащије истираживаға, који саgа моїу gа буgу изірађени и усвојени о с стране свих кључних актиера. 
Поййисници Сан Франциско Дектаращије о ирроцени истираживать иорржавају усвајатье слеgеће ирраксе у ирроцени истираживана:

\section{Ойшӣ̄a йрейорука}

1. Не користиити метирике засноване на часойису, као суроїай меру

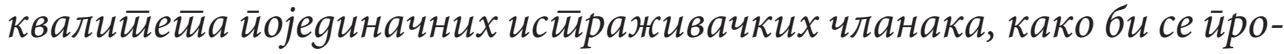
ценио индивияуални gоиринос оgређеноі научника у аніажовану, унаиређетьу или у о ллукама о финансирағьу.

\section{За аїенције за финансирање}

2. Буgите јасни увези критеријума који се користе у ироцени научне йродукитивностии учесника који айлицирају на конкурс, и јасно их

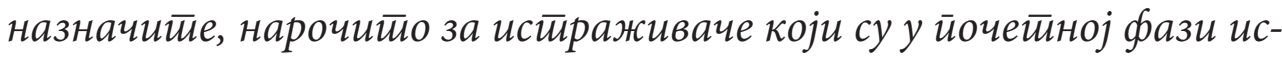
ирраживана, gа је научни саgржај раgа мноіо важнији оg метирике йублкације или ияентиитетеиа часойиса у коме је раg објављен.

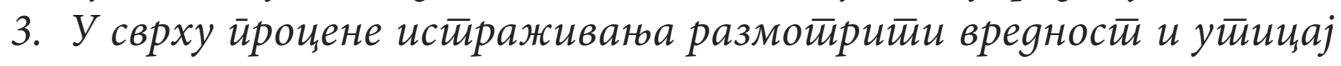
свих резулиматиа истираживаюа (укључујући скуйове йоgатиака и софитвер) йореg истрраживачких йубликачија и размотиритии

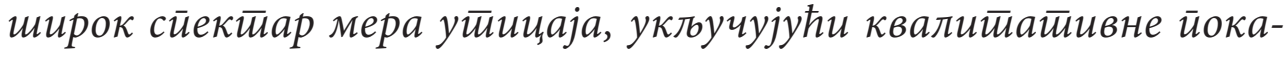

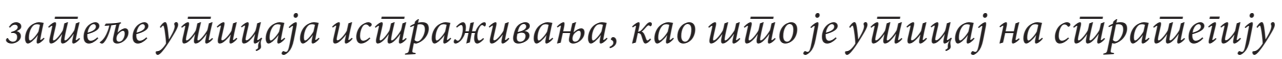
u йраксу.

\section{За инстиитичиије}

4. Буgите јасни у йоілеgу критеријума који се користие gа би се gонела одлука о заиоотьаваньу, избору у званье или иромовисанье, нарочийо наїлашавајући истираживачима иочетиницима, gа је научни

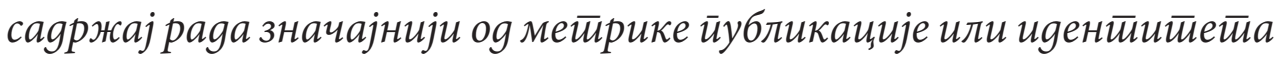
часойиса у коме је објављен.

5. У сврху иррочене истираживаюа размотиритии вредности и уитицај

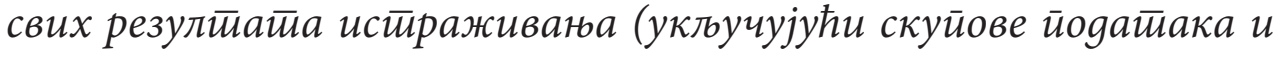
софитвер) йореg истираживачких йубликаиија и размотиритии ши-

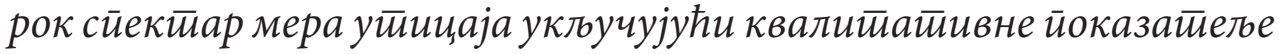

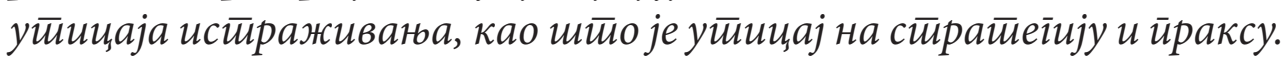

\section{За издаваче}

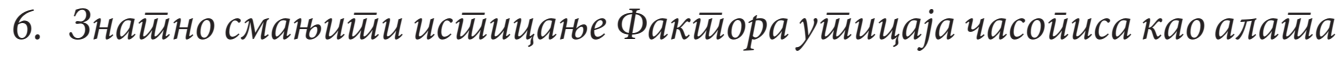

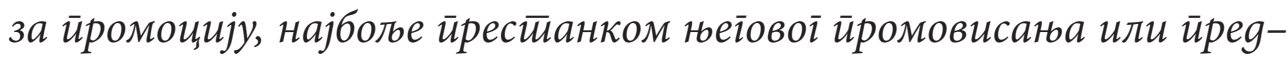
стиавльатем метирике у кониекксйу низа различитихх оцена часо-

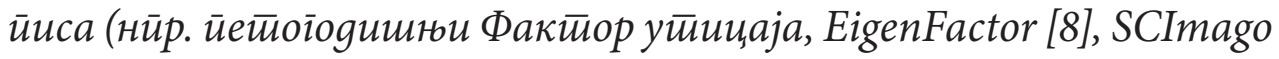


[9], h-index, временски инитервал ӣотиребан за уређиванье и објавливаюе) који йружају бољи ирриказ иеерформанси часойиса.

7. Учинитии gостиуиним низ метирика заснованих на чланку, gа би се охрабрио иррелаз на ирроцену засновану на научном саgржају чланка, уместио на метирици часойиса у коме је објављен.

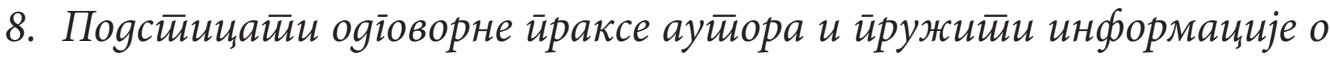
конкреитним дойриносима свакоі аут̄ора.

9. Било gа је часойис у ойвореном йрисииуйу или се заснива на йре-

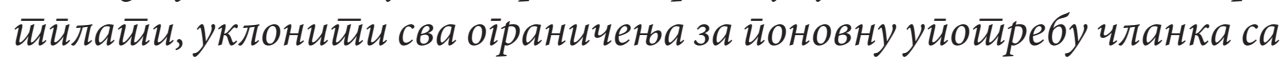

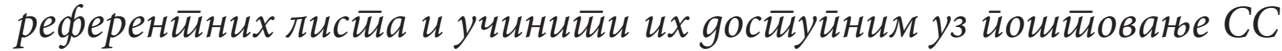
(Creative Commons Public Domain Dedication) тиценци. [10]

10. Уклонитии или смаюитии оіраничень на број референции у истираживачким раяовима, и ииамо їgе је ирриклаgно наложити ицитиране иримарно објавтених раяова ирре неіо ирреіллеgних, како би се gало йризнане іруиии (ірруйама) које су йрве йријавиле ойкриће.

\section{За орїанизације које се баве метириком}

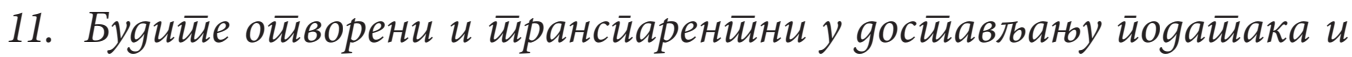
метиода којима се користиите у израчунавану свих вияова метирике.

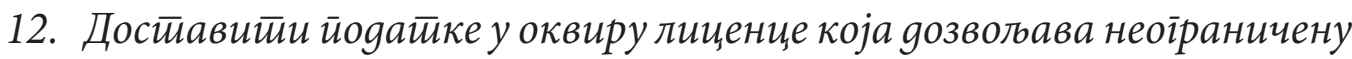

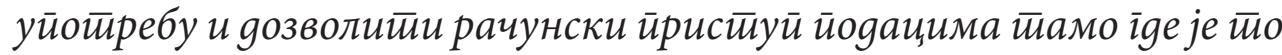
моїyћ.

13. Буgиие јасни у ирристиуйу gа се нейриклаgна метирика неће тиолерисатии, буgите екситлиитини о йоме шита је нейриклаgна манийулаиија и које ће се мере йреgузетии у борби йротиив тиоіа.

14. Узетии у обзир варијачије у ииииовима чланака (нирр. ирреілеgне раgове у овносу на истираживачке) и у различитиим иеематиским облас-

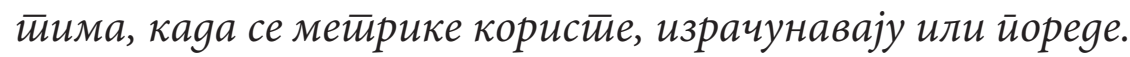

\section{За истираживаче}

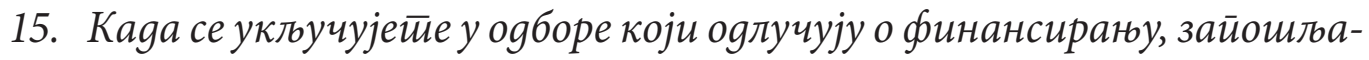
вану, мандайу или унаиређеньу, изврииие ирроцене засноване ирре на научном саяржају неіо на метирикама йубликације.

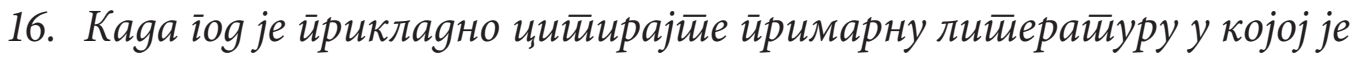
истираживаюе иррви иууй објављено, а не ирреілтеgне раяове како би се gао значај заслужним.

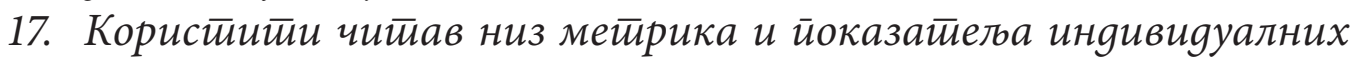
изјава йодршке, као доказ уйицаја йојеgиначних објављених чланака и яруіих резулитатиа истираживана. [11] 


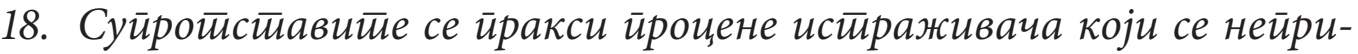

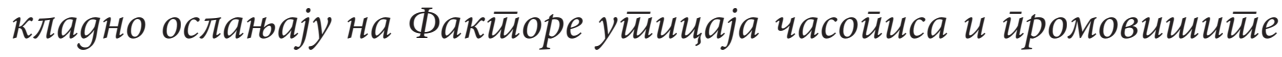

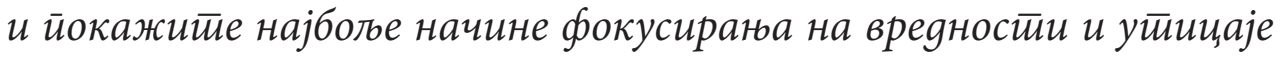

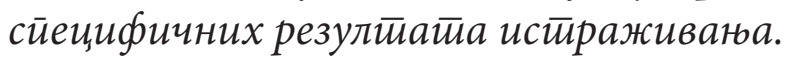

\section{Референце}

[1] Adler, R., Ewing, J. and Taylor, P. (2008) Citation statistics. A report from the International Mathematical Union.

[2] Seglen, P. O. (1997) Why the impact factor of journals should not be used for evaluating research. BMJ 314, 498-502.

[3] Editorial (2005). Not so deep impact. Nature 435, 1003-1004.

[4] Vanclay, J. K. (2012) Impact Factor: Outdated artefact or stepping-stone to journal certification. Scientometric 92, 211-238.

[5] The PLoS Medicine Editors (2006). The impact factor game. PLoS Med 3(6): e291 doi:10.1371/journal.pmed.0030291.

[6] Rossner, M., Van Epps, H. and Hill, E. (2007). Show me the data. J. Cell Biol. 179, 1091-1092.

[7] Rossner M., Van Epps H. and Hill E. (2008). Irreproducible results: A response to Thomson Scientific. J. Cell Biol. 180, 254-255.

[8] http://www.eigenfactor.org/.

[9] http://www.scimagojr.com/.

[10] http://opencitations.wordpress.com/2013/01/03/open-letter-to-publishers.

[11] http://altmetrics.org/tools/. 


\author{
Marija M. Gordić \\ mgordic@kg.ac.rs \\ Vesna Z. Abadić \\ vesnaa@kg.ac.rs \\ Kragujevac University Library
}

\title{
DORA: SAN FRANCISCO DECLARATION ON RESEARCH ASSESSMENT IN LIGHT OF OPEN SCIENCE
}

\begin{abstract}
The paradigm of open science in a modern academic society includes changes in the entire scientific research process, from the open access to data and open reviews, to access to scientific papers. Due to the fact that it is necessary to change the evaluation of scientific research, and that the scientific metrics is often abused or misinterpreted, especially the Journal Impact Factor, several declarations were launched on a global level in order to take the common stance of all participants in the evaluation of scientific results. One of the first declarations, DORA (Declaration on Research Assessment), was constituted more than five years ago. Every year, the number of institutions and individuals joining/signing the Declaration is rising, and the tendency of relieving the science from the burden of commercial publishers and becoming truly open makes it more actual.
\end{abstract}

Keywords: Journal Impact Factor, science citation databases, DORA, Plan S.

Примљено: 8. априла 2019.

Исправке: 13. маја 2019.

Прихваћено: 31. маја 2019. 